\title{
Effect of the feeding system and the production season on the protein fraction content in milk
}

\author{
Jolanta Król', Aneta Brodziak²*, Witold Chabuz³, \\ Zygmunt Litwińczuk³, Joanna Barłowska'
}

\author{
${ }^{1}$ University of Life Sciences in Lublin, Department of Commodity Science and Processing \\ of Raw Animal Materials, Akademicka 13, 20-950 Lublin, Poland \\ ${ }^{2}$ University of Life Sciences in Lublin, Laboratory for Organic Production of \\ Food of Animal Origin, Akademicka 13, 20-950 Lublin, Poland \\ ${ }^{3}$ University of Life Sciences in Lublin, Sub-Department of Cattle Breeding and Genetic \\ Resources Conservation, Akademicka 13, 20-950 Lublin, Poland \\ *Corresponding author: E-mail: aneta.brodziak@up.lublin.pl
}

\section{Abstract}

The objective of the present research was to analyse the protein fraction content in milk, with particular regard to whey proteins, in dependence on the cows' feeding system (group 1 - extensive, 2 - semi-intensive, 3 - intensive) and production season (spring-summer and autumn-winter). Chemical analysis of the fodder was the base for calculation of energy and protein coverage of nutritional dose. A total of 1,133 milk samples were evaluated (550 in winter and 583 in summer). The milk samples were examined for the somatic cell count (SCC), the basic chemical composition, casein and whey proteins: a-lactalbumin, $\beta$-lactoglobulin, bovine serum albumin (BSA), lactoferrin and lysozyme. Higher content of crude protein, including casein, was noticed in milk obtained from cows coming from semi-intensive and intensive farms. However, milk taken from cows fed according to the group 1, which was based on fodder from permanent grasslands, had the highest concentration of major whey proteins - both in the summer (pasture and hay) and winter (hay and haylage) seasons. With the increase of silage and industrial fodder in the feed ration, the content of whey proteins - mainly $\beta$-lactoglobulin and lactoferrin - decreased, which was confirmed by the obtained negative correlation coefficients.

Key words: whey proteins, extensive system, intensive system, correlations

\section{Introduction}

Quantity and quality of milk produced by cows, including the content of various fractions of proteins, depends on many factors, including the size and the composition of the feed ration, breed, season of production, animal health or stage of lactation (Król et al., 2017; Litwińczuk et al., 2011; Nahar et al., 2007; Turner et al., 2007). In Poland the great majority of dairy farms use a traditional system of feeding which is based on pasture forage. In comparison to total ration systems (TMR - Total Mixed Ration and PMR - Partially Mixed Ration) this system requires less financial expenditures but does not result in high productivity of cows. Numerous studies point to higher concentration of biologically active substances in the fat fraction of milk coming from cows fed in the traditional way, 
i.e. using the pasture (Carroll et al., 2006; Morales-Almaráz et al., 2011; Vranjes et al., 2010). According to Loor et al. (2003), the introduction of an 8-hour grazing daily at TMR diet significantly improves the health-promoting properties of milk. Barłowska and Litwińczuk (2006) indicated that milk obtained from the grazing cows was also characterised by better technological parameters (shorter time of curd formation and higher content of big-sized fat molecules (>10 $\mu \mathrm{m})$ ), especially for a cheese production. However, the effect of feeding system on the content of certain compounds in the protein fraction of milk is not well elucidated and described as in case of the fat fraction. The content of the total proteins in milk equals on average 3.2 $\%$, including approximately $20 \%$ of whey proteins. These are mainly albumins (approximately $75 \%$ ), i.e. $\beta$-lactoglobulin ( $\beta$-LG), a-lactalbumin ( $a-L A$ ) and bovine serum albumin (BSA). Whey proteins also include bacteriostatic substances, i.e. immunoglobulins, lactoferrin, lactoperoxidase and lysozyme. Whey proteins exhibit numerous effects on the human body, such as anti-inflammatory, bacteriostatic and antioxidant actions, which indicate their ability to prevent the occurrence of civilizational diseases like atherosclerosis, diabetes, obesity, cancer or Alzheimer's disease (Bhat and Bhat, 2011; Król et al., 2011). They are also a source of essential amino acids and are increasingly used to enrich baby foods, dietary medications or protein specimens for convalescents and athletes. Whey proteins also found their application in pharmacology and cosmetology (Graf et al., 2011; Sukkar and Iorio, 2011).

The aim of the work was to analyse the protein fraction content in milk, with particular regard to whey proteins, in dependence on the cows' feeding system and the production season..

\section{Materials and methods}

\section{Animals and feeding system}

The study involved 25 farms from the area of Eastern Poland keeping Polish Holstein-Friesian, Whitebacked, Polish Black and White and Polish Red and White cows. Farms selected for the study were divided into three groups according to the feeding system which was used (Table 1), i.e. group 1 with an extensive system - 8 farms; 2 (a semi-intensive system) - 8 farms and 3 (an intensive system) - 9 farms. On the farms from groups 1 and 2 all breeds of cows were kept. However, in group 3 Polish Holstein-Friesian and crossbreeds of Polish Holstein-Friesian with analysed breeds were maintained.

Farms belonging to group 1 had a semi commercial character, and the average size of cow herd was $15 \pm 5$ cows. The land structure was dominated by permanent pasture; maize was not grown. Feed from the permanent grassland accounted for about $80 \%$ of the cow diet - i.e. $58.1 \%$ from pasture (cows grazing throughout the day with breaks for milking and tending) and $20.4 \%$ from hay in the summer. However, this ration for the winter season was $52.8 \%$ from haylage and $27.1 \%$ from hay. The remaining $20 \%$ of the ration was ground grain. The mean milk production per lactation and a herd was $4,300 \mathrm{~kg}$.

The semi-intensive milk production system characterised farms classified into group 2 . The average number of cows in the herd was $28 \pm 10$ heads, and permanent grassland in the structure of land accounted for a half of the area. A whole day (from morning to evening milking) pasturing was used. The share of the fodder from pasture was $52 \%$ (pasture $-31.1 \%$, hay $-2.3 \%$ and haylage - $18.6 \%$ ) in the summer season but in the winter only $38 \%$ (hay - $7.0 \%$ and silage - $31.2 \%$ ). The share of the maize silage was $22.2 \%$ in the summer and in the winter it was the primary fodder in ration (37.2\%). Concentrated feed, as in group 1 , covered about $20 \%$ of nutritional requirements of cows but with an addition of industrial fodder ( $14.2 \%$ in the summer and $7.8 \%$ in the winter). Generally, they were complete feed and extracted meals. The mean milk production per lactation for herd was $6,100 \mathrm{~kg}$.

Farms in group 3 had a typical intensive type. The number of cows was on average $70 \pm 15$ heads. Structure of the agricultural land was dominated by arable land, where mainly maize on silage was grown. Throughout the year the cows were fed a mono-diet, i.e. in the majority of farms in a form of complete ration of PMR (ad libitum) which included: maize silage $(37.0 \%$ in the summer and 37.6 $\%$ in the winter), haylage $(29.3 \%$ in the summer and $31.5 \%$ in the winter) and addition of ground 
grain in the amount of $10 \%$. Industrial concentrat- $\quad$ in the winter, were delivered individually in a feed ed fodder (feed concentrates and complete feed), station according to daily milk yield. The mean milk in the amount of $24.8 \%$ in the summer and $27.1 \%$ production per lactation for herd was $8,000 \mathrm{~kg}$.

TABLE 1. Mean ( \pm SD) composition, energy and protein coverage of nutritional dose in dependence on feeding system and production season

\begin{tabular}{|c|c|c|c|c|c|c|c|c|c|c|}
\hline \multirow{4}{*}{ 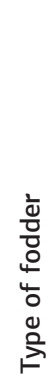 } & & \multicolumn{9}{|c|}{ Group of farms } \\
\hline & & \multicolumn{3}{|c|}{$\begin{array}{c}1 \\
n=8\end{array}$} & \multicolumn{3}{|c|}{$\begin{array}{c}2 \\
n=8\end{array}$} & \multicolumn{3}{|c|}{$\begin{array}{c}3 \\
n=9\end{array}$} \\
\hline & & $\begin{array}{l}\text { के } \\
\text { एँ } \\
\text { ज् }\end{array}$ & 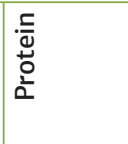 & 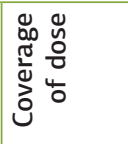 & वे & $\begin{array}{l}. \frac{5}{0} \\
\stackrel{\Delta}{0} \\
\text { 인 }\end{array}$ & 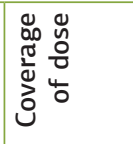 & 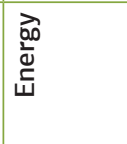 & 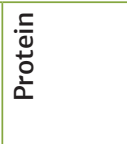 & 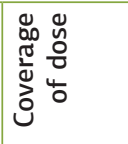 \\
\hline & & UFL & PDI (g) & $\%$ & UFL & PDI (g) & $\%$ & UFL & PDI (g) & $\%$ \\
\hline \multirow{16}{*}{ 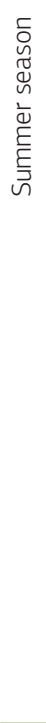 } & Pacture & 6.9 & 701 & 58.1 & 418 & 437 & 31.1 & - & - & - \\
\hline & Pascure & 0.3 & 165 & 5.1 & 1.1 & 127 & 9.1 & - & - & - \\
\hline & Maize cilago & - & - & - & 3.6 & 250 & 22.2 & 7.1 & 487 & 37.0 \\
\hline & IVIalze Siage & - & - & - & 1.4 & 91 & 8.0 & 1.2 & 91 & 2.7 \\
\hline & & 2.5 & 268 & 20.4 & 0.3 & 34 & 2.3 & - & - & - \\
\hline & Hay & 1.0 & 123 & 7.4 & 0.5 & 55 & 4.2 & - & - & - \\
\hline & Havara & - & - & - & 21.3 & 306.3 & 18.6 & 40.1 & 621 & 29.3 \\
\hline & Maylage & - & - & - & 9.2 & 126.3 & 6.9 & 9.9 & 82 & 4.4 \\
\hline & Filling formo & 2.6 & 229 & 21.6 & 1.7 & 139 & 11.6 & 1.6 & 129 & 8.9 \\
\hline & 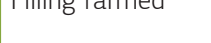 & 1.7 & 53 & 4.6 & 1.5 & 124 & 10.1 & 1.0 & 86 & 6.5 \\
\hline & Filling inductrial & - & - & - & 2.4 & 333 & 14.2 & 4.8 & 651 & 24.8 \\
\hline & 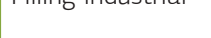 & - & - & - & 1.7 & 212 & 8.6 & 1.4 & 175 & 7.0 \\
\hline & Totat at a & 12.0 & 1198.8 & 100 & 15.8 & 1501.9 & 100 & 19.1 & 1889.6 & 100 \\
\hline & Tolar & 1.1 & 271.6 & & 2.3 & 287.6 & & 2.7 & 185.2 & \\
\hline & $\%$ of requirement & 98.5 & 121.5 & & 99.1 & 105.7 & & 106.1 & 105.9 & \\
\hline & coverage & 5.2 & 12.7 & & 4.0 & 6.9 & & 6.9 & 3.3 & \\
\hline \multirow{14}{*}{ 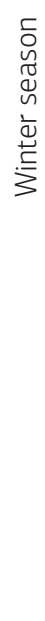 } & Maize cila & - & - & - & 4.9 & 360 & 37.2 & 7.6 & 513 & 37.6 \\
\hline & & - & - & - & 0.8 & 68 & 2.6 & 0.6 & 48 & 2.2 \\
\hline & Hav & 3.0 & 321 & 27.1 & 0.8 & 86 & 7.0 & - & - & - \\
\hline & May & 0.9 & 118 & 9.3 & 0.6 & 66 & 5.5 & - & - & - \\
\hline & Havla & 5.9 & 630 & 52.8 & 4.1 & 458 & 31.2 & 6.3 & 640 & 31.5 \\
\hline & Maylage & 4.1 & 169 & 12.1 & 0.6 & 94 & 4.6 & 0.9 & 67 & 3.7 \\
\hline & Filling farmed & 2.3 & 201 & 20.1 & 2.2 & 182 & 16.7 & 0.7 & 60 & 3.7 \\
\hline & 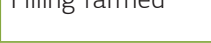 & 0.6 & 58 & 4.3 & 0.6 & 48 & 3.2 & 1.0 & 80 & 5.0 \\
\hline & Filling in & - & - & - & 1.1 & 249 & 7.8 & 5.5 & 708 & 27.1 \\
\hline & rimlng mudstrid & - & - & - & 0.6 & 131 & 4.1 & 0.9 & 98 & 4.2 \\
\hline & Totat & 11.2 & 1154.0 & 100 & 13.1 & 1338.3 & 100 & 20.1 & 1923.5 & 100 \\
\hline & & 1.4 & 212.8 & & 1.7 & 249.5 & & 1.2 & 112.1 & \\
\hline & $\%$ of requirement & 89.7 & 111.5 & & 98.7 & 101.6 & & 106.6 & 103.3 & \\
\hline & coverage & 2.5 & 5.9 & & 8.1 & 7.2 & & 2.9 & 3.8 & \\
\hline
\end{tabular}

Group of farms according to feeding system: 1 - an extensive system, 2 - a semi-intensive system, 3 - an intensive system UFL - feed unit for lactation

$\mathrm{PDI}$ - protein digested in the small intestine 
TABLE 2. Mean ( \pm SD) content and daily yield of basic milk components in the summer and the winter seasons

\begin{tabular}{|c|c|c|c|c|c|c|c|c|c|c|c|c|c|c|c|c|}
\hline \multicolumn{3}{|c|}{ Specification } & \multicolumn{2}{|c|}{$\begin{array}{c}\text { No. of } \\
\text { samples }\end{array}$} & \multicolumn{2}{|c|}{ Milk yield } & \multicolumn{2}{|c|}{ Fat } & \multicolumn{2}{|c|}{ Crude protein } & \multicolumn{2}{|c|}{ Casein } & \multicolumn{2}{|c|}{ Lactose } & \multicolumn{2}{|c|}{ Dry matter } \\
\hline & & & $\mathrm{S}$ & W & $S$ & w & $\mathrm{S}$ & W & $\mathrm{S}$ & W & $\mathrm{S}$ & W & $\mathrm{S}$ & W & $\mathrm{S}$ & w \\
\hline \multirow{12}{*}{ 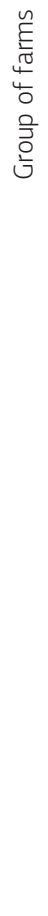 } & \multirow{4}{*}{-} & \multirow{2}{*}{ 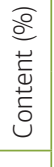 } & \multirow{4}{*}{$\infty$} & \multirow{4}{*}{ 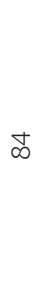 } & & - & $3.95^{\mathrm{A}}$ & 4.04 & $3.28^{A}$ & 3.34 & $2.45^{\mathrm{A}}$ & $2.43^{a}$ & $4.69^{\mathrm{AB}}$ & 4.75 & $12.54^{\mathrm{A}}$ & $12.78^{a}$ \\
\hline & & & & & & & 0.60 & 0.49 & 0.31 & 0.36 & 0.33 & 0.36 & 0.27 & 0.25 & 0.80 & 0.73 \\
\hline & & \multirow{2}{*}{ 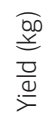 } & & & $16.05^{\mathrm{A}}$ & $14.38^{A}$ & $0.66^{A}$ & $0.58^{A}$ & $0.57^{A}$ & $0.48^{A}$ & $0.42^{\mathrm{A}}$ & $0.35^{A}$ & $0.82^{A}$ & $0.70^{A}$ & $2.17^{A}$ & $1.85^{\mathrm{A}}$ \\
\hline & & & & & 4.35 & 5.74 & 0.23 & 0.25 & 0.19 & 0.19 & 0.15 & 0.15 & 0.26 & 0.29 & 0.70 & 0.76 \\
\hline & \multirow{4}{*}{$\sim$} & o & \multirow{4}{*}{$\stackrel{\stackrel{N}{N}}{\sim}$} & \multirow{4}{*}{$\stackrel{\curvearrowright}{N}$} & - & - & $3.98^{\mathrm{A}^{* *}}$ & $4.27^{* *}$ & $3.28^{\mathrm{A}^{* *}}$ & $3.47^{* *}$ & $2.51^{\mathrm{AB}}$ & $2.50^{a}$ & $4.61^{A^{*}}$ & $4.76^{*}$ & $12.59^{\mathrm{A}^{* t}}$ & $13.15^{\mathrm{b}^{* x}}$ \\
\hline & & $\bar{\jmath}$ & & & - & - & 0.62 & 0.56 & 0.39 & 0.36 & 0.35 & 0.41 & 0.27 & 0.32 & 0.86 & 0.81 \\
\hline & & \multirow{2}{*}{ 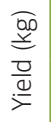 } & & & $21.11^{\mathrm{B}^{* *}}$ & $17.31^{\mathrm{B}^{* *}}$ & $0.93^{B^{* *}}$ & $0.74^{\mathrm{B}^{*+}}$ & $0.77^{\mathrm{B}^{* *}}$ & $0.60^{\mathrm{B}^{* *}}$ & $0.58^{\mathrm{B}^{*}}$ & $0.43^{B^{*}}$ & $1.07^{\mathrm{B}^{*}}$ & $0.85^{\mathrm{B}^{*}}$ & $2.93^{B^{* *}}$ & $2.31^{\mathrm{B}^{* *}}$ \\
\hline & & & & & 6.20 & 6.99 & 0.34 & 0.31 & 0.24 & 0.24 & 0.19 & 0.18 & 0.34 & 0.36 & 0.94 & 0.94 \\
\hline & \multirow{4}{*}{$m$} & $\frac{\grave{a}}{2}$ & \multirow{4}{*}{$\stackrel{\curvearrowright}{N}$} & \multirow{4}{*}{$\stackrel{\text { a }}{\stackrel{1}{v}}$} & - & - & $4.53^{B^{* *}}$ & $4.28^{* *}$ & $3.56^{\mathrm{B}}$ & 3.51 & $2.66^{\mathrm{B}}$ & $2.62^{b}$ & $4.77^{\mathrm{B}}$ & 4.74 & $13.52^{\mathrm{B}^{+t}}$ & $13.18^{\mathrm{btz}}$ \\
\hline & & ن & & & - & - & 0.59 & 0.60 & 0.41 & 0.46 & 0.42 & 0.40 & 0.24 & 0.32 & 0.90 & 0.99 \\
\hline & & \multirow{2}{*}{ 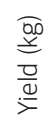 } & & & $27.33^{c}$ & $28.25^{c}$ & $1.16^{\mathrm{C}}$ & $1.24^{c}$ & $0.90^{c^{*+}}$ & $1.02^{\mathrm{C}^{* *}}$ & $0.67^{c^{*+}}$ & $0.76^{\mathrm{C}^{* *}}$ & $1.21^{c^{*}}$ & $1.37^{C^{*}}$ & $3.44^{\mathrm{C}^{*+}}$ & $3.82^{\mathrm{C}^{* *}}$ \\
\hline & & & & & 6.82 & 7.15 & 0.39 & 0.30 & 0.29 & 0.24 & 0.24 & 0.18 & 0.38 & 0.35 & 1.09 & 0.87 \\
\hline \multicolumn{5}{|c|}{ Interaction } & & & & & & & & & & & \multicolumn{2}{|r|}{ P-value } \\
\hline \multicolumn{5}{|c|}{$\begin{array}{l}\text { Production season } \\
\text { x feeding system }\end{array}$} & & 0.001 & 0.001 & & \multicolumn{2}{|c|}{0.001} & \multicolumn{2}{|c|}{0.008} & \multicolumn{2}{|c|}{0.001} & \multicolumn{2}{|r|}{0.001} \\
\hline
\end{tabular}

Group of farms according to feeding system: 1 - an extensive system, 2 - a semi-intensive system, 3 - an intensive system

$\mathrm{S}$ - summer season, $\mathrm{W}$ - winter season

a, b, A, B - differences between feeding groups within season

a, $b$ - differences significant at $P<0.05 ; A, B$ - differences significant at $P<0.01$

${ }^{*},{ }^{* *}$ - differences between seasons within feeding group

* - differences significant at $\mathrm{P}<0.01 ;{ }^{* *}$ - differences significant at $\mathrm{P}<0.001$

\section{Sampling and analyses}

In each farm the samples of all farm fodder, i.e. green forage, silage, hay and ground grain, were taken for analyses simultaneously with the milk samples. Results of chemical analyses of the fodder were the basis to calculate the mean composition, energy and protein coverage of the nutritional dose in the INRA feeding system (INRAtion 4.07 Software). Individual theoretical ration was calculated for each cow in the INRA system in dependence on daily yield on the day of milk sampling. A total of 1,133 rations were created, in that 550 during the summer period of feeding and 583 during the winter feeding. The energy value was expressed in terms of net energy lactation (UFL - feed unit for lactation). Protein intake was given in grams of protein truly digestible in the small intestine (PDI).

All of the farms were included in the Milk Recording runs by the Polish Federation of Cattle Breeders and Dairy Farmers.

Milk samples were collected in the years 20142016 on each farm individually from healthy cows between $30^{\text {th }}$ and $240^{\text {th }}$ day of lactation, twice a 
year, i.e. in the summer (June-July) and winter (December-January) production seasons. Only milk samples with the somatic cell count (SCC) below 400,000 cells/mL (using a flow cytometry technology - Somacount 150 apparatus, Bentley Instruments, USA) were included into the study. The average SCC in milk obtained from different groups according to the feeding system amounted as follows: 1 - 306,000, 2 - 288,000 and 3 - 319,000 cells / $\mathrm{mL}$.

In total 1,133 samples (in 550 samples from the summer and 583 from the winter) were analysed for the following parameters:

/ the basic chemical composition, i.e. content of fat, protein, lactose and dry matter - Infrared Milk Analyzer (Bentley Instruments, USA);

I the casein percentage - according to the AOAC (2000; method 998.06);

/ the concentration of whey proteins, i.e. a-lactalbumin (a-LA), $\beta$-lactoglobulin ( $\beta$-LG), bovine serum albumin (BSA), lactoferrin and lysozyme, in skimmed milk - using reverse-phase high-performance liquid chromatography (RP-HPLC). The procedure of whey protein separation was based on the method elaborated by Romero et al. (1996) with own modifications (Brodziak et al., 2012). Protein analysis was performed using the liquid chromatography ProStar 210 model and UV-Vis ProStar 325 detector (Varian, USA). The measurements were carried out using the water/acetonitrile mobile phase at gradient elution and column NUCLEOSIL 300-5 C18 (Varian, USA) of 250 mm length and $4.6 \mathrm{~mm}$ diameter. The total analysis time for a single sample was $35 \mathrm{~min}$ at $205 \mathrm{~nm}$ wavelength with column temperature of $37^{\circ} \mathrm{C}$. The analyses of reference substances were conducted under the same conditions. On the grounds of the obtained chromatograms, using program Star 6.2 Chromatography Workstation (Varian, USA), the qualitative and quantitative identification of each substance was performed.

Calibration of the chromatographic system for whey proteins determination was carried out by the external standard method. For this purpose, each protein was calibrated individually by injecting solu- tions of the standards $(20 \mu \mathrm{L})$. Purified proteins, i.e. a-LA ( $\geq 85 \%), \beta$-LG (90\%), bovine albumin serum $(\geq 96 \%)$ and lactoferrin (90\%) all from bovine milk, as well lysozyme (95\%) from hen egg whites, which were purchased from Sigma (Germany) were used as standards. All chemicals were of HPLC analytical grade.

\section{Statistical analyses}

The results obtained were analysed statistically using the General Linear Model (GLM) - factorial ANOVA procedures of Statsoft Inc. Statistica ver. 8 (Statsoft Inc. 2013), on the ground of one- and twoway analysis of variance with interaction. Means and standard deviations were given for individual analysed traits. The significance of differences between means was estimated by Duncan's test (for farms) and HSD Tukey's test (for milk samples) at $\mathrm{P} \leq 0.05$ level. The statistical analysis included the effect of feeding system and production season, using the following linear model:

$$
Y_{i j}=\mu+a_{i}+b_{j}+\left(a_{i} \times b_{j}\right)+e_{i j}
$$

where: $Y_{i j}$ - dependent variable, $\mu$ - effect of total mean, $a_{i}$ - effect of feeding system $(i=1 . .3), b_{j}$ effect of production season $(j=1,2),\left(a_{i} \times b_{j}\right)$ - effect of interaction of two factors, $e_{i j}$ - random error.

To establish the relationships between experimental variables, i.e. share of energy from each fodder in the feed ration and the analysed milk components including proteins, the Spearman's rank correlation coefficients were calculated. A value of $\mathrm{P}<0.05$ was considered as significant.

\section{Results and discussion}

According to many authors, a composition of feeding ration is a crucial factor influencing changes in the chemical composition of milk (Carroll et al., 2006; Delaby et al., 2009; Król et al., 2017; Morales-Almaráz et al., 2011; Nahar et al., 2007), but also a breed plays an important role (Brodziak et al., 2012; Król et al., 2017; Kř́ižová et al., 2013). In every season, milk obtained from cows belonging to the farms from group 1 (Table 2) was found as 
the poorest source of nutrients. Therefore, it can be assumed that in this group the model did not fully cover the nutritional requirements of cows for nutrients, especially for energy. However, the animals fed the rations with maize silage and concentrated feed (group 2 and 3) produced milk with higher content of basic chemical components. Milk of cows in group 3, with regard to milk of cows in group 1 , contained significantly more dry matter - from 0.40 to $0.98 \%(P<0.05$ and $P<0.01)$, including fat - from 0.24 to $0.58 \%(P<0.01)$ and crude protein - from 0.17 to $0.28 \%(P<0.01)$, depending on the season of production. These relationships were confirmed by the higher values of positive correlation coefficients between the content of individual milk com- ponents and the share of silage and concentrated feed in the ration (Table 4). Use of the complete ration in feeding of animal from group 3 in both seasons resulted in an increase in daily milk yield as well as yield of individual milk components (Table 2). Significantly lower $(P<0.01)$ yield achieved cows in groups 1 and 2. In comparison to group 1, even a twice higher yield of milk and its basic components were noted in group 3 in the winter season. Effect of use of more intensive feeding system (i.e. a more balanced ration) on increase of milk yield and its nutritional value was confirmed by studies of other authors (Morales-Almaráz et al., 2011; Vranjes et al., 2010; Zamani et al., 2011).

TABLE 4. Correlation coefficients ( $r$ ) between share of energy in feeding dose from chosen fodder (UFL) and content of analysed milk components

\begin{tabular}{|c|c|c|c|c|c|c|c|}
\hline & \multirow[t]{2}{*}{ Milk components } & \multicolumn{6}{|c|}{ Share of energy from the fodder } \\
\hline & & Pasture & $\begin{array}{l}\text { Maize } \\
\text { silage }\end{array}$ & Hay & Haylage & $\begin{array}{l}\text { Filling } \\
\text { farmed }\end{array}$ & $\begin{array}{l}\text { Filling } \\
\text { industrial }\end{array}$ \\
\hline \multirow{11}{*}{ 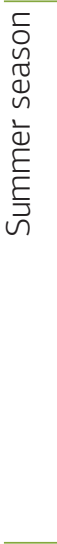 } & Fat & -0.04 & $0.41^{*}$ & -0.05 & $0.37^{*}$ & $-0.17^{*}$ & $0.52^{*}$ \\
\hline & Crude protein & $-0.15^{*}$ & $0.19^{*}$ & $-0.12^{*}$ & $0.13^{*}$ & -0.02 & $0.39 *$ \\
\hline & Casein & -0.03 & $0.13^{*}$ & 0.02 & $0.10^{*}$ & $-0.16^{*}$ & $0.31^{*}$ \\
\hline & Protein to fat ratio & 0.04 & $-0.33^{*}$ & 0.06 & $-0.34^{*}$ & $0.19^{*}$ & $-0.31^{*}$ \\
\hline & Lactose & -0.05 & $0.32^{*}$ & $0.17^{*}$ & $0.31^{*}$ & -0.02 & $0.23^{*}$ \\
\hline & Dry matter & -0.00 & $0.42^{*}$ & -0.04 & $0.37^{*}$ & $-0.13^{*}$ & $0.55^{*}$ \\
\hline & $a-L A$ & $0.13^{*}$ & $-0.32^{*}$ & 0.01 & -0.27 & 0.07 & $-0.25^{*}$ \\
\hline & $\beta$-LG & $0.19^{*}$ & $-0.55^{*}$ & 0.05 & $-0.49^{*}$ & $0.23^{*}$ & $-0.43^{*}$ \\
\hline & BSA & $-0.18^{*}$ & $0.10^{*}$ & $-0.19^{*}$ & 0.01 & $-0.15^{*}$ & $0.13^{*}$ \\
\hline & Lactoferrin & $0.21^{*}$ & $-0.72^{*}$ & 0.10 & $-0.60^{*}$ & $0.31^{*}$ & $-0.50^{*}$ \\
\hline & Lysozyme & -0.06 & $-0.33^{*}$ & 0.05 & $-0.26^{*}$ & 0.06 & $-0.26^{*}$ \\
\hline \multirow{11}{*}{ 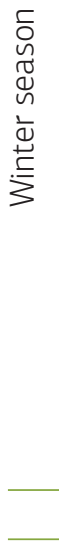 } & Fat & & $0.22^{*}$ & -0.11 & $-0.15^{*}$ & $0.10^{*}$ & $0.13^{*}$ \\
\hline & Crude protein & & 0.02 & -0.12 & -0.08 & 0.09 & $0.18^{*}$ \\
\hline & Casein & & 0.07 & $-0.11^{*}$ & 0.12 & -0.01 & $0.17^{*}$ \\
\hline & Protein to fat ratio & & 0.04 & -0.02 & 0.05 & 0.01 & 0.05 \\
\hline & Lactose & & -0.03 & 0.08 & -0.01 & $0.15^{*}$ & 0.01 \\
\hline & Dry matter & & 0.07 & -0.10 & $-0.14^{*}$ & 0.14 & $0.12^{*}$ \\
\hline & $a-L A$ & & $-0.13^{*}$ & $0.17^{*}$ & $-0.09^{*}$ & 0.05 & -0.05 \\
\hline & $\beta$-LG & & $-0.32^{*}$ & 0.01 & $-0.20^{*}$ & -0.10 & $-0.28^{*}$ \\
\hline & BSA & & $0.17^{*}$ & -0.07 & $0.15^{*}$ & 0.03 & $0.23^{*}$ \\
\hline & Lactoferrin & & $-0.39 *$ & $0.25^{*}$ & $-0.22^{*}$ & $0.16^{*}$ & $-0.52^{*}$ \\
\hline & Lysozyme & & $-0.34^{*}$ & -0.13 & $-0.36^{*}$ & 0.05 & $-0.28^{*}$ \\
\hline
\end{tabular}

a-LA - a-lactalbumin, $\beta$-LG - $\beta$-lactoglobulin, BSA - bovine serum albumin

* - differences significant at $P<0.05$ 
Kruczyńska (2011) stated that maize silage was fundamental to bacterial protein synthesis in the rumen and has a positive impact on the quantity of milk. Nahar et al. (2007), however, found that feeding cows with green fodder and feed concentrates increased the dry matter content in milk, including proteins and fat. A crucial component of milk, due to technological usefulness, is casein. According to Mackle et al. (1999), its concentration in milk might be affected by diet of cows, even in $10 \%$. Application of complete doses and feed con- centrates containing protein and protected amino acids (group 3) increased the share of casein in milk in comparison to milk of cows from group 2 (by $5 \%$ in the winter $-\mathrm{P}<0.05$ and $6 \%$ in the summer $\mathrm{P}<0.01$ ) and group 1 (by $8 \%$ in the winter $-\mathrm{P}<0.05$ and $9 \%$ in the summer $-P<0.01$ ). Confirmation of these results were outcomes of some other authors (Brodziak et al. 2018; Cermanová et al., 2011; Król et al., 2008), who reported lower content of casein in milk of grazing cows.

TABLE 3. Mean ( \pm SD) content of chosen whey proteins in analysed milk of cows in the summer and winter seasons

\begin{tabular}{|c|c|c|c|c|c|c|c|c|c|c|c|c|}
\hline \multirow{2}{*}{\multicolumn{3}{|c|}{ 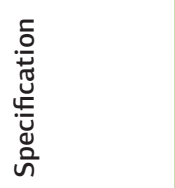 }} & \multicolumn{2}{|r|}{$a-L A$} & \multicolumn{2}{|r|}{$\beta$-LG } & \multicolumn{2}{|r|}{ BSA } & \multicolumn{2}{|c|}{ Lactoferrin } & \multicolumn{2}{|r|}{ Lysozyme } \\
\hline & & & $\mathrm{S}$ & w & $\mathrm{S}$ & w & $\mathrm{S}$ & w & $\mathrm{S}$ & w & $\mathrm{s}$ & w \\
\hline \multirow{12}{*}{ 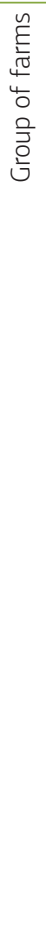 } & \multirow{4}{*}{-} & \multirow{2}{*}{ 䓂 } & $1.08^{b}$ & 1.00 & $3.54^{\mathrm{c} *^{* *}}$ & $3.26^{\mathrm{B}^{* *}}$ & $0.36^{A^{* *}}$ & $0.46^{* *}$ & $0.19^{c^{*+*}}$ & $0.12^{\mathrm{B}^{*+}}$ & $7.6410^{-6 \mathrm{AB}^{*+*}}$ & $12.3910^{-6} \mathrm{~B}^{* *}$ \\
\hline & & & 0.14 & 0.13 & 0.42 & 0.38 & 0.08 & 0.14 & 0.05 & 0.01 & $3.0910^{-6}$ & $8.1010^{-6}$ \\
\hline & & \multirow{2}{*}{ 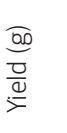 } & $18.35^{\mathrm{A}^{*}}$ & $14.39 \mathrm{~A}^{*}$ & $61.92^{A^{* *}}$ & $46.62^{A^{* *}}$ & $6.09^{A}$ & $7.02^{A}$ & $3.32^{\mathrm{B}^{*+}}$ & $1.766^{A^{*+}}$ & $123.0310^{-6 A^{*}}$ & $176.4610^{-6} \mathrm{a}^{*}$ \\
\hline & & & 5.20 & 6.44 & 22.29 & 20.69 & 3.10 & 3.80 & 1.38 & 0.80 & $65.0010^{-6}$ & $97.010^{-6}$ \\
\hline & \multirow{4}{*}{$\sim$} & \multirow{2}{*}{ 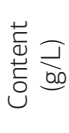 } & $1.066^{b^{*}}$ & $0.99 *$ & $3.34^{\mathrm{B}^{* *}}$ & $3.14^{A B^{* *}}$ & $0.42^{\mathrm{B}^{*}}$ & $0.48^{*}$ & $0.15^{\mathrm{B}^{*+}}$ & $0.11^{\mathrm{B}^{* *}}$ & $8.6510^{-6} \mathrm{~B}^{*}$ & $10.1510^{-6 \mathrm{AB}^{*}}$ \\
\hline & & & 0.51 & 0.15 & 0.52 & 0.43 & 0.22 & 0.13 & 0.04 & 0.02 & $3.6510^{-6}$ & $8.0110^{-6}$ \\
\hline & & \multirow{2}{*}{$\frac{0}{\frac{00}{0}}$} & $22.95^{\mathrm{B}^{*+}}$ & $16.95^{A B^{* *}}$ & $76.00^{B^{* *}}$ & $55.27^{\mathrm{B}^{* *}}$ & $10.64^{\mathrm{B}}$ & $8.62^{A}$ & $3.36 \mathrm{~B}^{\mathrm{B}+}$ & $1.88^{\mathrm{A}^{* *}}$ & $188.1210^{-6 \mathrm{C}}$ & $179.5910^{-6 a}$ \\
\hline & & & 6.40 & 7.56 & 22.54 & 21.74 & 7.71 & 4.33 & 1.37 & 0.86 & $84.9310^{-6}$ & $164.1910^{-6}$ \\
\hline & \multirow{4}{*}{$m$} & \multirow{2}{*}{ 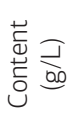 } & $0.96^{a}$ & 0.99 & $2.86^{A^{* *}}$ & $3.04 \mathrm{~A}^{* *}$ & $0.45^{\mathrm{B}}$ & 0.43 & $0.09^{A}$ & $0.08^{A}$ & $6.3110^{-6 \mathrm{~A}}$ & $7.5410^{-6} \mathrm{~A}$ \\
\hline & & & 0.13 & 0.12 & 0.33 & 0.25 & 0.17 & 0.09 & 0.02 & 0.01 & $3.4610^{-6}$ & $2.4110^{-6}$ \\
\hline & & \multirow{2}{*}{$\begin{array}{l}\frac{\widehat{D O}}{\square} \\
\frac{0}{ \pm}\end{array}$} & $26.63^{c^{* *}}$ & $27.96^{\mathrm{B}^{* *}}$ & $70.15^{A B^{* x}}$ & $84.99^{c * *}$ & $11.73^{B}$ & $12.88^{B}$ & $2.28^{\mathrm{A}^{* *}}$ & $2.35^{\mathrm{B}^{*+}}$ & $169.8410^{-6} \mathrm{~B}^{* *}$ & $215.6510^{-6} b^{* * t}$ \\
\hline & & & 8.44 & 7.48 & 22.36 & 22.13 & 5.34 & 5.05 & 0.82 & 0.96 & $92.0710^{-6}$ & $89.0710^{-6}$ \\
\hline \multicolumn{3}{|c|}{ Interaction } & \multicolumn{10}{|r|}{ P-value } \\
\hline \multicolumn{3}{|c|}{$\begin{array}{l}\text { Production } \\
\text { season } x \\
\text { feeding } \\
\text { system }\end{array}$} & \multicolumn{2}{|r|}{0.007} & \multicolumn{2}{|r|}{0.001} & \multicolumn{2}{|r|}{0.001} & \multicolumn{2}{|r|}{0.001} & \multicolumn{2}{|r|}{0.001} \\
\hline
\end{tabular}

Group of farms according to feeding system: 1 - an extensive system, 2 - a semi-intensive system, 3 - an intensive system

a-LA - a-lactalbumin, $\beta$-LG - $\beta$-lactoglobulin, BSA - bovine serum albumin

$S$ - summer season, $W$ - winter season

a, b, A, B - differences between feeding groups within season

a, b - differences significant at $\mathrm{P}<0.05 ; \mathrm{A}, \mathrm{B}$ - differences significant at $\mathrm{P}<0.01$

${ }^{*},{ }^{* *}$ - differences between seasons within feeding group;

* - differences significant at $P<0.01$;

** - differences significant at $\mathrm{P}<0.001$ 
The results presented in Table 3 indicate significant correlations between the content of the whey proteins in milk and the feeding systems of cows used. Both in the summer and winter seasons, the milk obtained from cows fed according to the model I (group 1) was characterised by the highest concentration of major whey proteins, i.e. $a-L A$, $\beta$-LG and lactoferrin. With the increase of silage and industrial fodder share in the ration, the content of $\beta$-LG and lactoferrin significantly $(P<0.01)$ decreased. In the winter, the content of $\beta$-LG in milk of cows from group 2 decreased by $0.12 \mathrm{~g} / \mathrm{L}$, in comparison to group 1, and in group 3 - by $0.22 \mathrm{~g} / \mathrm{L}$, while for lactoferrin - 0.01 and $0.04 \mathrm{~g} / \mathrm{L}$, respectively. Greater statistically significant $(P<0.01)$ differences between these two groups were observed in the summer. In group 2 , the amount of $\beta$-LG was reduced by $0.20 \mathrm{~g} / \mathrm{L}$ (by $6 \%$ with regard to group 1 ), while in group 3 even by $0.68 \mathrm{~g} / \mathrm{L}$ (by $19 \%$ ). Lactoferrin concentration decreased respectively by $0.04 \mathrm{~g} / \mathrm{L}$ (less by $27 \%$ in comparison to group 1 ) and $0.10 \mathrm{~g} / \mathrm{L}$ in group 3 (by $53 \%$ ). These relationships were confirmed by the obtained negative correlation coefficients (Table 4). The highest values of these coefficients were stated in the summer season between lactoferrin concentration and the share of maize silage $(r=-0.72$ at $P<0.05)$, haylage $(r=-0.60$ at $P<0.05)$, as well industrial fodder $(r=$ -0.50 at $P<0.05)$. In the winter season, the obtained values were lower $(P<0.05)$, i.e. $r=-0.39, r=-0.22$ and $r=-0.52$, respectively. For $\beta$-LG the correlations were respectively: the summer ( $r=-0.55 ; r=-0.49$ and $r=-0.43$, at $P<0.05)$ and the winter $(r=-0.32 ; r=-0.20$ and $r=-0.28$, at $P<0.05$ ). With a greater percentage of the pasture in feed ration, the contents of $\beta$-LG and lactoferrin increased in milk, which was confirmed by the obtained correlation coefficients ( $\beta$-LG - r=0.19 and lactoferrin - $r=0.21$, at $P<0.05$ ) - Table 4. The higher level of functional whey proteins in milk of grazing cows was also shown by Król et al. (2008) and Mackle et al. (1999). According to them, a higher share of whey proteins in grazing cows' milk results from the higher content of bioactive components in fresh forage. Carroll et al. (2006) stated that not limited (ad libitum) access to the green feed (pasture) causes the increase in valuable milk components i.e. in the not saturated fatty acids and the share of the total solids. However, Turner et al. (2007) found that unrestricted access to pasture (ad libitum) did not lead to an increase in concentration of lactoferrin in milk. During the winter feeding period, the hay was the feed that had the greatest influence on lactoferrin content $(r=0.25$ at $P<0.05)$. In the summer, hay supplementation led, to a lesser extent, to this protein increase in milk $(r=0.10)$. Thus, it can be assumed that the decisive influence on the content of lactoferrin in milk analysed was noticed for a share of roughages derived from permanent grasslands, i.e. from pasture in the summer and hay in the winter period. The seasonal differences in the content of $a-L A, \beta-L G$ and lactoferrin in milk were also obsereved. The highest level of these proteins (with regard to the feeding system, excluding group 3) was found in the summer, which corresponded well to the results of other studies (Wedholm et al., 2006; Litwińczuk et al., 2011; Brodziak et al., 2018). A larger share of industrial fodder in ration negatively affected the content of lysozyme in milk ( $r=-0.26$ - summer; $r=-0.28$ - winter). Regardless of the production season, the least amount of lysozyme was obtained in milk of cows fed a total ration (group 3). There were no differences in the BSA content between the feeding systems in the winter. Its concentration was at the level of 0.43 $0.48 \mathrm{~g} / \mathrm{L}$. Significant (at $\mathrm{P}<0.05$ ) differences were noticed, however, in the summer. Milk of grazing cows (group 1) was characterised by the smallest concentration of BSA, which was also confirmed by the negative correlation coefficient obtained $(r=-0.18$ at $P<0.05)$. Moreover, the share of industrial fodder and silage in the ration affected the growth of this protein fraction in milk. Similar tendencies were reported by Brodziak et al. (2012; 2018) and Mackle et al. (1999). Mackle et al. (1999), who showed that energy absorbed in the ration might affect the concentration of whey proteins in milk of cows, also including the serum proteins. They also noted that the content of major whey proteins, i.e. $\mathrm{a}-\mathrm{LA}$ and $\beta$-LG, decreased while the level of BSA increased when the animals had no access to pasture. However, Kř́žzová et al. (2013) obtained statistically higher content of total whey proteins in milk of cows from non-grazed herds $(0.51 \%)$ with regard to grazed animals (0.47 \%).

With respect to the daily yield of individual whey proteins (Table 3), the cows in group 3 were generally characterised by the highest yield of whey 
proteins, although the lowest content of these components were found in their milk, which was most probably related to the greatest quantity of milk produced by the animals in this group. It should be noted that higher yields of $\beta$-LG, lactoferrin and lysozyme were found in group 2 in the summer season.

\section{Conclusion}

The significant effect of feeding system of cows on chemical composition of milk, including the whey protein content, was shown. With the in- crease of silage and industrial fodder share in the ration, the percentage of basic milk components increased. However, the content of $\beta$-LG and lactoferrin decreased, which was confirmed by the obtained negative correlation coefficients. Regardless of the production season, the highest concentration of the major whey proteins characterised the milk taken from cows belonging to group 1 , which was based on the fodder from permanent grasslands. Therefore, it could be assumed that a decisive influence on the content of whey proteins in milk was noticed for the share of roughages derived from permanent grasslands, i.e. from pasture in the summer and hay in the winter period.

\section{Utjecaj sustava hranidbe i sezone laktacije na udjel proteina u mlijeku}

\section{Sažetak}

Cilj ovog istraživanja bio je analizirati sadržaj proteinske frakcije mlijeka, s posebnim naglaskom na protein sirutke, ovisno o sustavu hranidbe krava (grupa 1 - ekstenzivni, 2 - djelomično intenzivni, 3 intenzivni) kao i sezoni laktacije (proljeće-ljeto i jesen-zima). Kemijske analize krmiva bile su temelj za izračun dostatnosti energije i proteina u dnevnom unosu nutrijenata. Ukupno je ispitano 1133 uzorka mlijeka (550 zimi i 583 ljeti), a određivani su ukupan broj somatskih stanica (SCC), osnovni kemijski sastav, te udjeli kazeina i proteina sirutke - a-laktalbumin, $\beta$-laktoglobulin, albumin krvnog seruma (BSA), laktoferin i lizozim. Viši udio ukupnih proteina, uključujući kazein, utvrđen je u mlijeku krava s farmi s djelomično intenzivnim i intenzivnim sustavom hranidbe. Međutim, neovisno o sezoni laktacije, najveće koncentracije proteina sirutke utvrđene su u mlijeku krava svrstanih u grupu 1, čija se hranidba temeljila na kontinuiranoj ispaši (ljeti - ispaša i sijeno; zimi - sijeno i silaža). Porastom udjela silaže i industrijskih krmiva u hranidbi, udjel proteina sirutke (prije svega $\beta$-laktoglobulina i laktoferina) je padao, što je potvrđeno i dobivenim negativnim koeficijentima korelacije.

\section{Ključne riječi: protein sirutke, ekstenzivni sustav, intenzivni sustav, korelacije}

\section{References}

1. AOAC (2000): Official Method of Analysis. ( $17^{\text {th }}$ ed.) Casein in milk, 998.06. AOAC International, Arlington, VA.

2. Barłowska, J., Litwińczuk, Z. (2006): Technological usefulness of milk from two local breeds maintained in the regions with great grassland share. Archives Tierzucht Spec. Issue 49, 207-213.

3. Bhat, Z.F., Bhat, H. (2011): Milk and dairy products as functional foods: a review International Journal of Dairy Science 6, 1, 1-12

https://doi.org/10.3923/ijds.2011.1.12
4. Brodziak, A., Barłowska, J., Król, J., Litwińczuk, Z. (2012): Effect of breed and feeding system on content of selected whey proteins in cow's milk in spring-summer and autumnwinter seasons. Annals of Animal Sciences 12, 2, 261-269. https://doi.org/10.2478/v10220-012-0022-6

5. Brodziak, A., Król, J., Litwińczuk, Z., Barłowska, J. (2018): Differences in bioactive protein and vitamin status of milk from certified organic and conventional farms. International Journal of Dairy Technology 71, 2, 321-332. https://doi.org/10.1111/1471-0307.12462 
6. Carroll, S., De Peters, E., Taylor, S., Rosenberg, M., PerezMonti, H., Capps, V. (2006): Milk composition of Holstein, Jersey and Brown Swiss cows in response to increasing levels of dietary fat. Animal Feed Science and Technology 131, 451-473. https://doi.org/10.1016/j.anifeedsci.2006.06.019

7. Cermanová, I., Hanuš, O., Roubal, P., Vyletělová, M., Genčurová, V., Jedelská, R., Kopecký, J., Dolinková, A. (2011): Effect of organic farming on selected raw cow milk components and properties. Acta Universitatis Agriculturae et Silviculturae Mendelianae Brunensis 59 (6), 81-92. https://doi.org/10.1016/j.anifeedsci.2006.06.019

8. Delaby, L., Faverdin, P., Michel, G., Disenhaus, C., Peyraud, J.L. (2009): Effect of different feeding strategies on lactation performance of Holstein and Normande dairy cows. Animal 3 (6), 891-905. https://doi.org/10.1017/S1751731109004212

9. Graf, S., Egert, S., Heer, M. (2011): Effects of whey protein supplements on metabolism: Evidence from human intervention studies. Current Opinion in Clinical Nutrition and Metabolic Care 14 (6), 569-580. https://doi.org/10.1097/MCO.0b013e32834b89da

10. KY̌rižová, L., Hanuš, O., Roubal, P., Kučera, J., Hadrová, S. (2013): The effect of cattle breed, season and type of diet on nitrogen fractions and amino acid profile of raw milk. Archives Tierzucht 56 (71), 709-718. https://doi.org/10.7482/0003-9438-56-071

11. Król, J., Brodziak, A., Litwińczuk, A. (2011): Basic chemical composition and content of selected whey proteins in milk from different cow breeds and in rennet whey. Zywnosc Nauka Technologia Jakosc 4 (77), 74-83. https://doi.org/10.15193/zntj/2011/77/074-083

12. Król J., Brodziak A., Litwińczuk Z., Zaborska A. (2017): Comparison of whey proteins and lipophilic vitamins between four cow breeds maintained in intensive production system. Mljekarstvo 67 (1), 17-24.

13. Król, J., Litwińczuk, Z., Litwińczuk, A., Brodziak, A. (2008): Content of protein and its fractions in milk of Simental cows with regard to a rearing technology. Annals of Animal Sciences 1, 57-61.

14. Kruczyńska, H. (2011): Roughage - silage. Cattle 4, 12-15.

15. Litwińczuk, Z., Król, J., Brodziak, A., Barłowska, J. (2011): Changes of protein content and its fractions in bovine milk from different cow breeds subject to somatic cell count. Journal of Dairy Science 94, 684-691. https://doi.org/10.3168/jds.2010-3217

16. Loor, J.J., Soriano, F.D., Lin, X., Herbein, J.H., Polan, C.E. (2003): Grazing allowance after the morning or afternoon milking for lactating cows fed a total mixed ration (TMR) enhances trans 11-18:1 and cis9, trans11-18:2 (rumenic acid) in milk fat to different extents. Animal Feed Science and Technology 109, 105-119. https://doi.org/10.1016/S0377-8401(03)00175-5
17. Mackle, T.R., Bryant, A.M., Petch, S.F., Hooper, R.J., Auldist, M.J. (1999): Variation in the composition of milk protein from pasture-fed dairy cows in late lactation and the effect of grain and silage supplementation. New Zealand Journal of Agricultural Research 42, 147-154. https://doi.org/10.1080/00288233.1999.9513364

18. Morales-Almaráz, E., de la Roza-Delgado, B., González, A., Soldado, A., Rodríguez, M.L., Peláez, M., Vicente, F. (2011): Effect of feeding system on unsaturated fatty acid level in milk of dairy cows. Renewable Agriculture and Food Systems 26 (3), 224-229. https://doi.org/10.1017/S1742170511000019

19. Nahar, A., Al-Amin, M., Wadud, A., Monir, M.M., Khan, M.A.S. (2007): Effect of partial green grass over dry feeding on the productive performance of early lactating crossbred cows in Bangladesh. International Journal of Dairy Science 2 (1), 73-78. https://doi.org/10.3923/ijds.2007.73.78

20. Romero, C., Perez-Andujar, O., Jimenes, S. (1996): Detection of cow's milk in ewe's or goat's milk by HPLC. Chromatographia 42, 181-184. https://doi.org/10.1007/BF02269650

21. Statsoft Inc. Statistica ver.8 (Statsoft Inc. 2013).

22. Sukkar, S.G., Iorio, E.L. (2011): Whey proteins. Overview of clinical trials, Progress in Nutrition 13 (Suppl. 1), 35-44.

23. Turner, S.A., Thomson, N.A., Auldist, M.J. (2007): Variation of lactoferrin and lactoperoxidase in bovine milk and the impact of level of pasture intake. New Zealand Journal of Agricultural Research 50, 33-40. https://doi.org/10.1080/00288230709510280

24. Vranjes, A.P., Krajinovic, M., Kecman, J., Trivunovic, S., Pejanovic, R., Krajinovic, G., Macak, G. (2010): Comparison of fatty acid composition in conventional and organic milk. Mljekarstvo 60 (1), 59-66.

25. Wedholm, A., Hallén, E., Larsen, L.B., Lindmark-Månsson, H., Karlsson, A.H., Allmere, T. (2006): Comparison of milk protein composition in a Swedish and a Danish dairy herd using reversed phase HPLC. Acta Agriculturae Scandinavica Section A, Animal Science 56, 8-15. https://doi.org/10.1080/09064700600836745

26. Zamani, P., Miraei-Ashtiani, S.R., Alipour, D., Tabatabaei, M., Aliarabi, H., Saki, A.A., Maleki, M., Abdolmohammadi, A. (2011): Statistical analysis of some factors affecting crude protein balance in lactating dairy cows. Journal of Agricultural Science and Technology 13, 1033-1043. 